\title{
Sustainable oil and gas production in the 21 st century with emphasis on offshore fields
}

\author{
O. T. Gudmestad \\ Department of Mechanical and Structural Engineering \\ and Material Science, University of Stavanger, Norway
}

\begin{abstract}
We foresee that oil and gas will continue to be the key energy sources in the 21st century. Therefore, it is important that oil and gas be produced in a sustainable way during the next decades. This will require technology development to ensure that the environmental impact and pollution from these activities are minimal. The following aspects are highlighted in this paper:

- Development of projects with the minimum of impact on the environment and problems for local populations;

- Sustainable drilling without the use of oil-based mud, and collection of all drilling waste during Arctic offshore drilling operations;

- Treatment of produced water, sand and minerals from the well stream to avoid pollution;

- Limitation of flaring to be performed only when required for safety reason;

- Continuous checking of pipelines to ensure that gas pipelines are run within their actual pressure capacity and that oil pipelines are not leaking into rivers and lake;

- Provision of sufficient storage capacity for gas to ensure timely delivery of gas during high demand peak;

- Injection of $\mathrm{CO}_{2}$ into sealed underground formations where large quantities are produced, such as at LNG factory;

- Optimization of production from existing fields to avoid huge amounts of oil and gas being left in place, following a "hit and run" recovery plan.

Keywords: sustainable oil and gas production, minimal impact on the environment, pollution, treatment of produced water, flaring, storage, $\mathrm{CO}_{2}$ injection.
\end{abstract}




\section{Introduction}

The trend in today's energy market in Europe is for huge subsidies to be transferred to develop renewable energy sources like wind and solar energy. Gas is by some considered to be a pollutant and the suggestion is that it be phased out, along with nuclear power. There are, however, severe problems with this trend. A stable 24-hours-a-day request for energy cannot be provided by the renewable sources. Therefore, coal-fired plants are used for back up. When started up, these plants lead to large amounts of emissions. The fact is that the total amount of emissions in Europe is increasing.

In China a large number of coal-fired plants are being built, leading to increased amounts of smog in many of the big cities. The pollution is so severe that living in these cities carries a great health risk. As an example, in October of 2013, the traffic lights in Harbin had to be shut down as they were not visible to car drivers $[1,2]$. Winter heating systems fired by coal were blamed, in part, for the crisis (Figure 1).

This leads us back to the use of gas as a stable source of energy, with far less emissions than coal and with a much smaller risk of large accidents than the use of nuclear power. This statement is particularly true when the production and use of gas is carried out in a sustainable way, where the focus is on the minimization of emission from production.

In this paper we will, therefore, discuss measures to limit pollution from oil and gas production and also discuss how the pollution from the use of gas as energy source can be further minimized. Of main concern is the emission of $\mathrm{CO}_{2}$

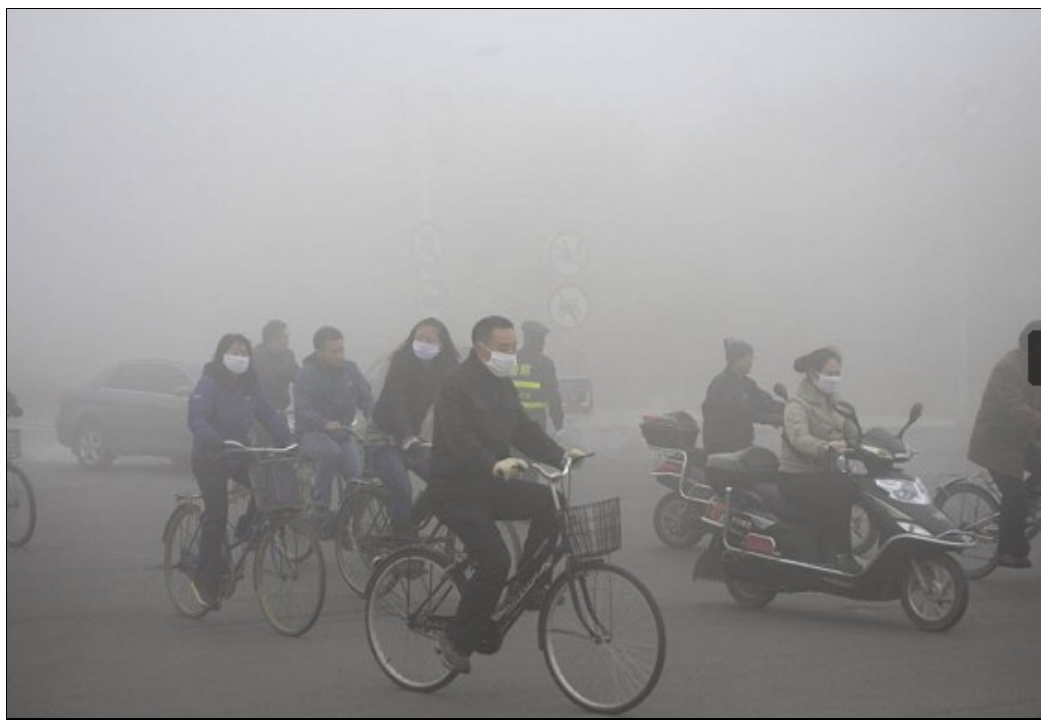

Figure 1: $\quad$ People ride along a street on a smoggy day in Daqing, Heilongjiang province, China, October 2013 [2]. 
from the burning of gas and liquid fuels. In the US there is a drive to limit emissions from power plants and heavy trucks [3], reducing the global warming trend. Some scientists are much concerned that a drastic limitation of $\mathrm{CO}_{2}$ emission is necessary to avoid atmospheric overheating and huge climate changes.

Without a dramatic transfer from the use of coal to the use of gas, reducing the $\mathrm{CO}_{2}$ emissions seems an impossible goal. Therefore, we consider the use of gas produced in a sustainable way as a key to meeting the emission targets to be set by the international community.

In this respect, it should be noted that the average emission rates in the United States from natural gas-fired generation are: $1135 \mathrm{lbs} / \mathrm{MWh}$ of carbon dioxide, $0.1 \mathrm{lbs} / \mathrm{MWh}$ of sulfur dioxide, and $1.7 \mathrm{lbs} / \mathrm{MWh}$ of nitrogen oxides. On the other hand, the average emissions rates in the United States from coal-fired generation are: $2249 \mathrm{lbs} / \mathrm{MWh}$ of carbon dioxide, $13 \mathrm{lbs} / \mathrm{MWh}$ of sulfur dioxide, and $6 \mathrm{lbs} / \mathrm{MWh}$ of nitrogen [4]. The traditional direct burning of chunks of coal and of coal briquettes, as occurs in Chinese households, accounts for large contributions to the air pollution in China, and such burning exhibits more pollution than that from coal-fired plants.

\section{Economics of sustainable oil and gas developments}

The economy plays an important role in industry. Decisions regarding projects must be based on economic considerations amongst technical well-developed solutions where technical maturity, safety and clean environment have been considered.

In this context, the word "sustainable" means that all relevant aspects have been taken into account and that the physical environment is not destroyed by the industrial enterprise. Unfortunately, there are industrialized areas where the industry is not "sustainable". Among these are Nikel, a mining city in Northern Russia, close to the Norwegian border, where the emission of sulfur and heavy metals has destroyed the vegetation in a large area around the city (Figure 2). A dead zone of elliptic shape is formed, depending on the wind directions. There are reasons to suggest that the environment should be brought back to its original status and that the government should interfere in such situations.

In the following discussion we will assume that it is agreed amongst all partners in a project that the project shall take care of safety and the environment, regardless of whether this is more costly in the short term. If can be argued that "if one cannot afford safety, one could try the cost and the shame of an accident". Furthermore, one should notice the hugs costs of cleanup operations where the land is destroyed. In this respect, reference could be made to the vast area now out of farming production following the Chernobyl nuclear power plant catastrophe.

Having argued that all projects shall be "sustainable", this does not necessarily mean that projects will be totally emission free. It will not be possible to produce and use oil and gas without some emission and some pollution. According to US Environmental Protection Agency [4], the amount of 


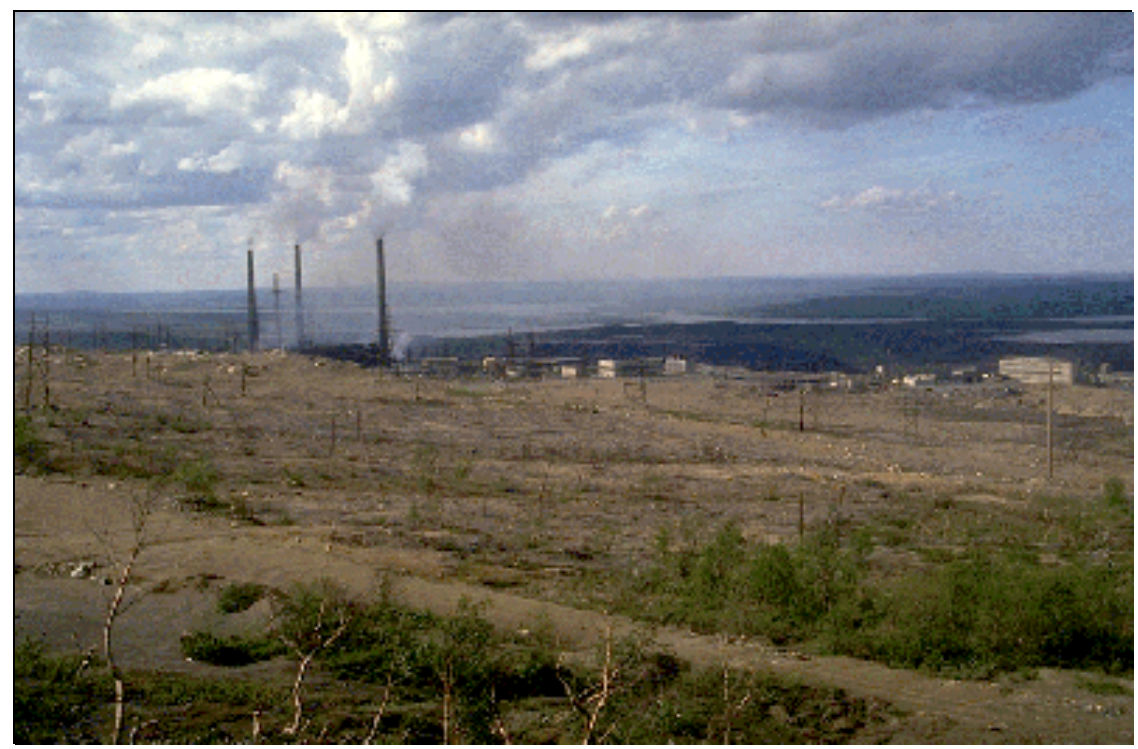

Figure 2: Emission of sulfur and heavy metals has destroyed the vegetation [5].

$\mathrm{CO}_{2}$ emission is on average 132 tons per 1000 tons of hydrocarbon produced and the amount of $\mathrm{CH}_{4}$ emission per 1000 tons is 1.3 tons. The optimal level of pollution marginal benefit of reducing pollution just equals the marginal cost. The quantity of contaminants in the air should be below the level of interference with human health, safety and comfort, expressed in parts per million [ppm], which conform to approved international standards.

\section{Methods for sustainable oil and gas production}

There are several sources of pollution and emission from oil and gas production (see Figure 3). For hydrocarbon production to be termed "sustainable", the emission must be reduced levels permissible by the international society and in agreement with international conventions. As seen from Figure 3, some of the pollution is to sea and some to air.

In the case of onshore drilling, there is no way to dilute produced water or sewage water by letting the polluted water to flow into the rivers, as a river carries a limited amount of water that easily becomes heavily polluted. Therefore, it will be necessary to collect and treat the polluted water.

\subsection{Drilling with environmentally degradable drilling mud}

Arctic offshore drilling without the use of oil-based mud and with the collection of all drilling waste represents a great environmental benefit. Environmentally friendly drilling mud should be biodegradable, and it should be possible to spread the drilling waste on the ground to enrich or rehabilitate the soil [7]. 


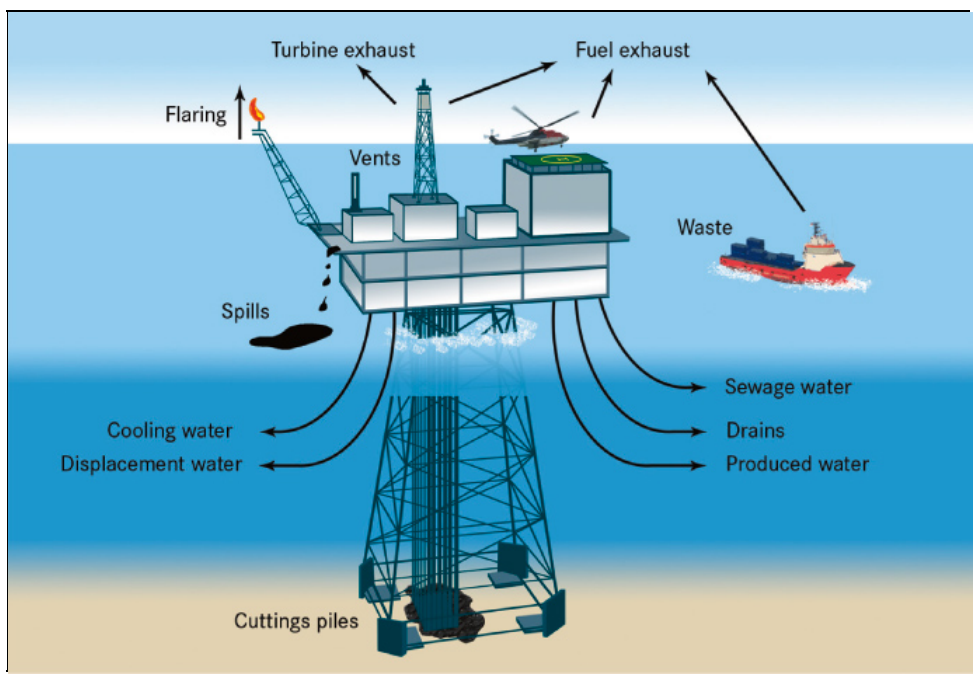

Figure 3: $\quad$ Pollution released from a range of sources during routine offshore oil and gas production [6]. It should, however, be noted that most of this pollution is taken care of during routine operations.

Offshore drilling in the North Sea primarily uses water-based mud with nonlethal additives. In the case of use of polluting mud, the mud is collected and cleaned onshore before being used for land reclamation.

\subsection{Treatment of well stream products}

The well stream will normally contain greenhouse gases like $\mathrm{CH}_{4}$ (methane) and other hydrocarbon gas components as well as water or traces of water, $\mathrm{CO}_{2}$ and or $\mathrm{H}_{2} \mathrm{~S}$, sand and heavy metals, and, in some cases, radioactive compounds. It is therefore a requirement that the well stream is treated in such a way that the sales products, the gas and the liquid components, are free from detrimental elements. When doing so, sufficient attention must be paid to the storage of the waste to avoid it causing a risk to health or polluting the environment [8].

Of particular concern are toxic gases, like $\mathrm{H}_{2} \mathrm{~S}$, in particular when causing a pile-up of large accumulations of sulfur in the Caspian region after processing the gas. Such piles of sulfur must be covered to avoid the spread of the toxic waste in wind. Of even larger concern is radioactive waste (normally low radioactivity), which must be handled with extreme care to avoid its being spread amongst the population.

\subsection{Treatment of produced water}

Some oil and gas fields produce large quantities of water. This water is contaminated by the hydrocarbon particles and has to be cleaned before it can be released to the environment, for example to a river or lake. In many situations, the river or lake cannot self-clean the remaining hydrocarbons, even if the 
concentration of hydrocarbon molecules is as low as some few parts per million. Furthermore, heavy metals diluted in the water may have even greater polluting effects than hydrocarbons. Dams have been created to purify polluted waters; however, we have seen that heavy rain may break the containment or the dam could dry out, leaving toxic dust to blow into the air. Recently, bacteria have been used to purify polluted water (Figure 4, from [9]) and this trend is expected to continue in the future.

An alternative will, of course, be to inject the pollutants into the underground, potentially as a driving fluid for increased oil production or more likely into separate permeable rock formations that are sealed, avoiding the injected pollutants returning to the surface or back into the hydrocarbon reservoir.

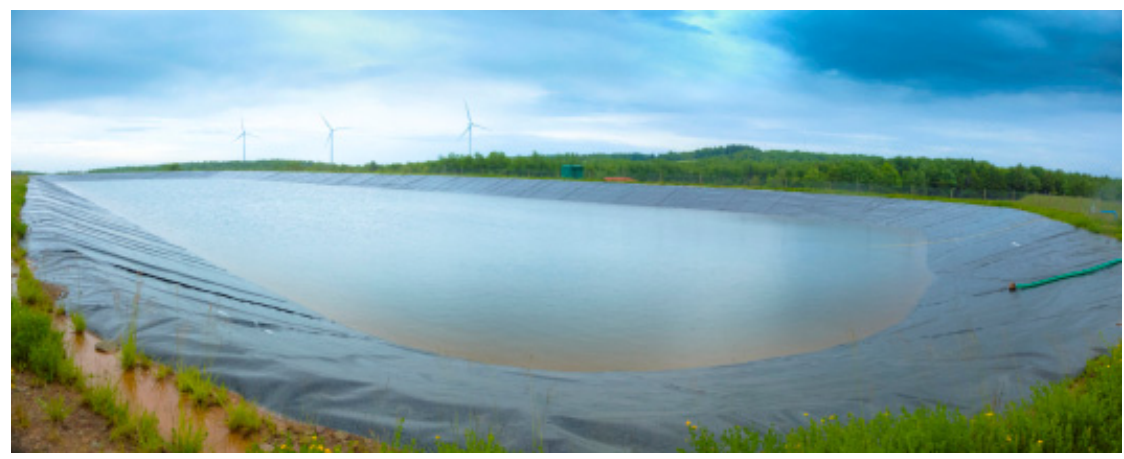

Figure 4: $\quad$ Dam to purify polluted water [9].

\subsection{Limitation of flaring to safety issues only}

Flaring of natural gas, as an unwanted byproduct of petroleum production, is a major challenge. Worldwide it is estimated that about 150 billion cubic meters are 'flared' in this manner each year, contributing to several hundreds of millions of tons of carbon dioxide into the atmosphere [10]. Several programs to avoid flaring are being implemented. These consist of gas collection for local heating, gas injection into separate reservoirs or gas injection into the gas cap of an oil reservoir to increase the oil production. The World Bank will deny loans to new developments based on gas flaring or the venting of excess gas, and some governments (including the Norwegian government) are becoming aware of flaring as bad practice and are imposing a tax on all flaring as well as on combustion gases from field facilities. The costs of these measures may be far smaller than the damage greenhouse gases could cause to the environment.

\subsection{Continuous checking of production equipment for leakages}

Every year, leakages from production equipment or transport facilities cause severe damage to the environment. In some places, as in the Niger Delta, the pollution is so severe that people's lives are at stake; access to clean water is 
difficult and pollution is found almost everywhere in the swampland. Figure 5 shows the situation after an oil spill in the Komi Republic. The costs of a proper clean-up are horrendous.

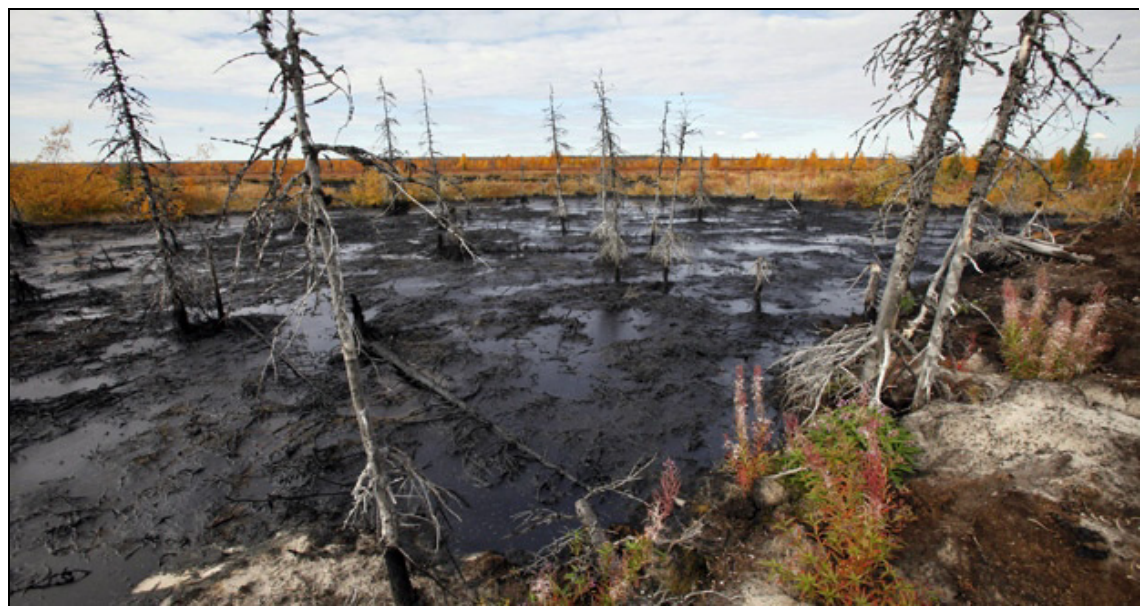

Figure 5: This photo, dated Sept. 10, 2011, shows the aftermath of an oil spill near the town of Usinsk, in Komi Republic. Ruptures in aging pipelines and leaks from decommissioned oil wells make oil spills in the region routine [12].

\subsection{Continuous checking of pipelines, in particular at river crossings}

Recently (October 2013), a smaller oil spill occurred at the Kharyaga oil field in Northern Russia. About two tons of oil spilled onto the tundra in connection with the accident [11]. The pipeline is operated by Lukoil and its regional subsidiary Lukoil-Usinskneftegaz. The spill was the third in a year; similar spills happened both in October 2012 (polluting 3.5 square kilometers of tundra) and in April 2013. According to [11], the oil spills were connected with the new pipelines laid in the area.

It should be noted that river crossings are particularly exposed to oil spills, as the riverbank will be eroded by the flow of the water in the river. The erosion is strongest in areas of permafrost, as warm river water will melt the shore permafrost and cause quicker erosion compared to rivers with more stable soil along established riverbanks. So, in cold climate regions, the potential for pipeline overstressing and leakages must be considered in the design stage when planning the transport infrastructure from the field (Figure 6).

It should also be noted that pipelines placed on slopes are vulnerable to slope movements and failures and that rain during warm summers is likely to cause failures of such sloping areas. Continuous checking is necessary to ensure the integrity of onshore pipelines and their valves. 


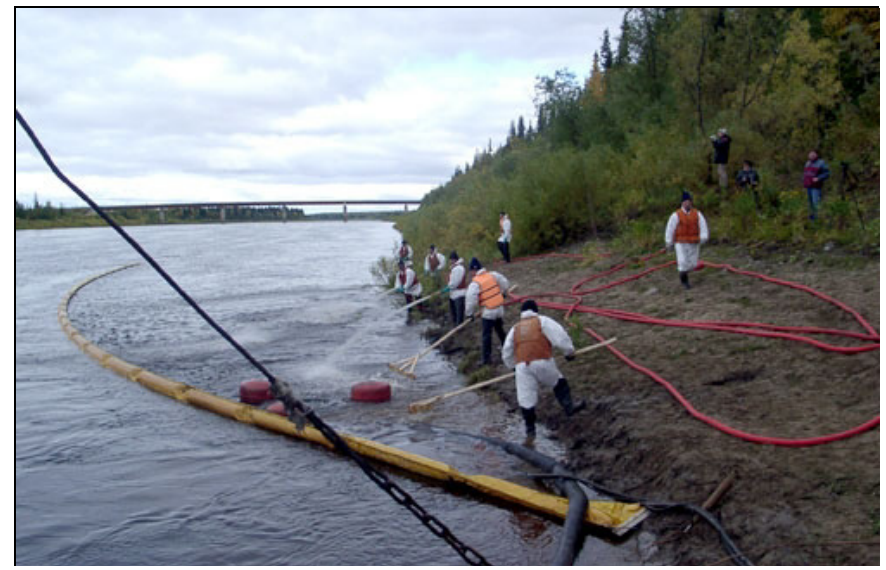

Figure 6: Oil spill cleanup. Training event from [10]. Photo by Lukoil, Komi.

\subsection{Availability of gas storage volumes}

The preparation of sufficient storage capacity for gas to ensure timely deliverability during high demand peaks is an important strategy to ensure that customers are satisfied with the reliability of the gas delivery. Gassco is the technical operator of the Norwegian gas transportation system where Statoil previously played a central role in establishing the system. The system, consisting of 7,925 km pipelines is integrated into the European gas network with access points in Scotland, Germany, Belgium, France and England.

In 2007 a new pipeline connected Norway with southern England to transport gas from the Ormen Lange field. Delivery regularity and operating flexibility are important parameters. As a consequence, the importance of gas storage has increased. There are three conceptual gas storage business models: sale of storage capacity, enhanced supply and trading. To meet its storage requirements, the Norwegian gas pipeline transportation system include two storage projects located in Aldbrough, UK and Etzel, Germany (Figure 7 [13]).

\subsection{Injection of $\mathrm{CO}_{2}$ into the ground}

The injection of $\mathrm{CO}_{2}$ into the ground at processing facilities where large quantities of $\mathrm{CO}_{2}$ are extracted, such as at production facilities or at LNG factories, is considered by some the key measure to the reduction of greenhouse gas release into the atmosphere from the oil and gas industry.

$\mathrm{CO}_{2}$ capture is performed at Statoil's Sleipner field by a conventional amine process. It was a challenge to design this process to be sufficiently compact to be placed on an offshore platform in the middle of the North Sea, 250 kilometers from land.

In 1990 the Statoil-operated gas/condensate field Sleipner Vest in the North Sea was in its planning phase. The natural gas at Sleipner innately contains around $9 \% \mathrm{CO}_{2}$, which was too much with respect to customer requirements. The $\mathrm{CO}_{2}$ needed to be removed first. 


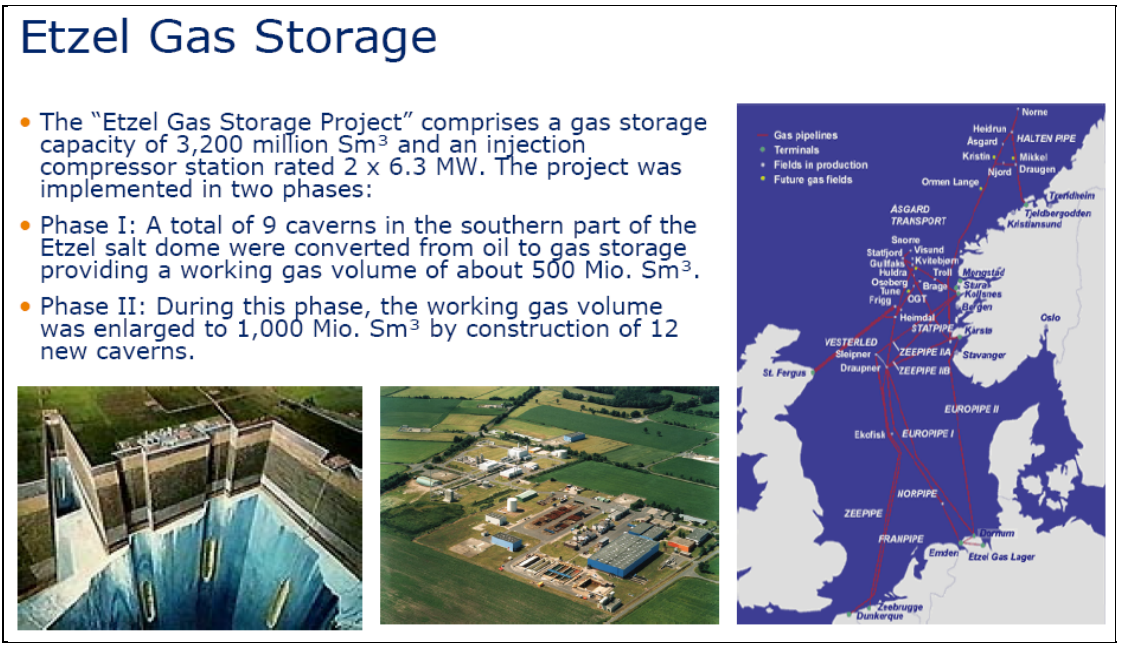

Figure 7: Specifics of the Etzel gas storage facilities [13].

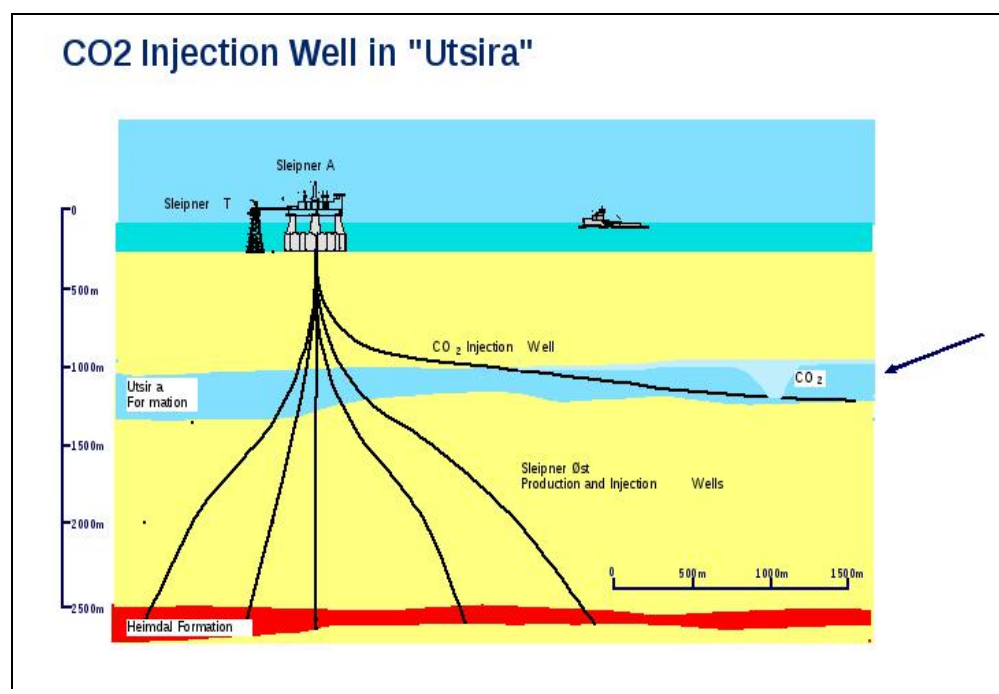

Figure 8: Injection of $\mathrm{CO}_{2}$ into the Utsira geological formation from Statoil's Sleipner field [13].

Furthermore, in 1991, the Norwegian authorities introduced a $\mathrm{CO}_{2}$ offshore tax with the aim of reducing $\mathrm{CO}_{2}$ emissions. Statoil then decided to remove the offshore $\mathrm{CO}_{2}$ and inject it into a deep geological layer below the Sleipner platform. This layer contains porous sand rock filled with salt water, and is called the Utsira formation. The $\mathrm{CO}_{2}$ is prevented from seeping into the 
atmosphere by an 800 meter thick gastight cap rock above this layer. Its implementation meant a reduction in $\mathrm{CO}_{2}$ emissions of nearly one million tons per year, which was roughly $3 \%$ of the Norwegian $\mathrm{CO}_{2}$ emissions in 1990 . The Sleipner field became operative in October 1996 [14].

\subsection{Optimization of production from existing wells and existing fields}

It is important that large quantities of oil and gas are not left the reservoir and to prevent the operator from adapting a "hit and run" development scheme, where only the most easily accessible oil is produced. The present worldwide oil recovery factor is just above $29 \%$. Furthermore, the worldwide amount of produced hydrocarbons today exceeds the results of exploration. The stock value of companies depends greatly on the recoverable oil to which the companies have access. Secondary and tertiary recovery methods, drilling of additional wells, artificial lift and upgrading of surface facilities provide for Improved Oil Recovery (IOR) and should be implemented in the volumes available to be produces (Figure 10 [15]).

Some years ago, Statoil prepared a model for future IOR additions worldwide. A weighted final recovery factor of $38 \%$ was estimated, corresponding to $700 \mathrm{Bbbls}$ additional production. IOR, however, poses many technical challenges and good planning is essential. We should also notice that the term EOR (Figure 9) represents Enhanced Oil Recovery, indicating production of oil that normally would not be produced, thus differing from IOR, oil that can be produced with traditional means.

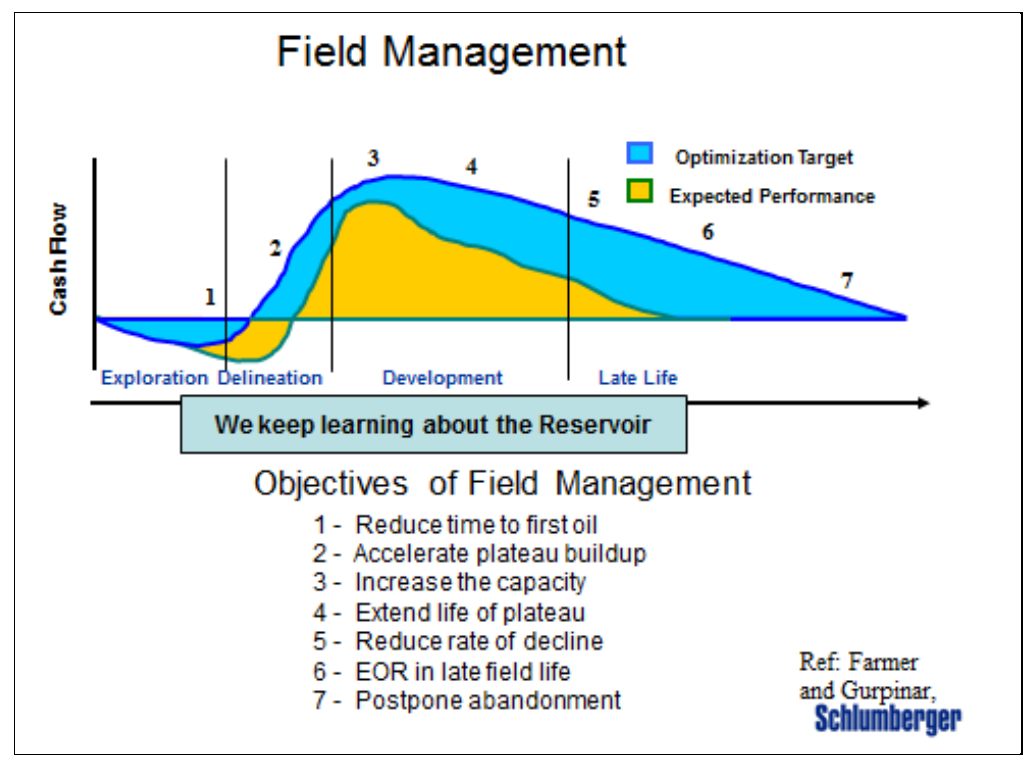

Figure 9: $\quad$ Field management incorporating Increased Oil Recovery [15]. 


\section{Conclusions}

We suggest that:

- "Sustainable oil and gas production" should become mandatory in all future petroleum field operations

- An emerging trend where renewable power is backed up by coal-fired plants, which emit more than double the amount of greenhouse gases per MWh into the atmosphere, as compared to the use of gas needs to be reconsidered

- In order to term oil and gas production as "sustainable", efforts must be made to ensure that hydrocarbon fuels are produced and utilized with a minimum of environmental impact.

\section{Acknowledgement}

This work is based on cooperation and discussions with Kjell Traa, a senior Norwegian expert on the use of gas for sustainable developments.

\section{References}

[1] http://news.nationalgeographic.com/news/energy/2013/10/131022-harbinice-city-smog-crisis-china-coal/ Accessed on $30^{\text {th }}$ November 2013.

[2] http://www.telegraph.co.uk/news/worldnews/asia/china/10396198/Chinese -city-of-Harbin-shrouded-in-smog-as-air-pollution-soars.html Accessed on $30^{\text {th }}$ November 2013.

[3] http://www.scientificamerican.com/article.cfm?id=obamas-climate-planwill-limit-emissions-from-plants-and-trucks Accessed on $30^{\text {th }}$ November 2013.

[4] United States Environmental Protection Agency. "Clean energy, air emissions". http://www.epa.gov/cleanenergy/energy-and-you/affect/airemissions.html Accessed on $30^{\text {th }}$ November 2013.

[5] http://www.ngu.no/Kola/cd2-03.gif. Accessed on 30 ${ }^{\text {th }}$ November 2013.

[6] Ospar Commission (2010). "Quality Status Report", Chapter 7. http://qsr2010.ospar.org/en/ch07 01.html Accessed on $30^{\text {th }}$ November 2013.

[7] Williamson, D. (2013). "Drilling fluid basics". Oilfield Review, 25 no 1, pp. 63-64.

[8] Gudmestad, O.T., A. B. Zolotukhin and E. Jarlsby (2010). "Petroleum resources with emphasis on offshore fields", WIT Press, Southampton, UK June 2010, ISBN-10: 1845644786, ISBN-13: 978-1845644789.

[9] University of Minnesota (2013). "Purifying bad water with good bacteria", http://researchumn.com/2013/04/30/purifying-bad-water-with-goodbacteria/ Accessed on $30^{\text {th }}$ November 2013.

[10] IPIECA and OGP (2011). "Preparing effective flare management plans. Guidance document for the oil and gas industry". IPIECA and OGP, 
London, OGP Report No 467. http://www.ogp.org.uk/pubs/467.pdf Accessed on $30^{\text {th }}$ November 2013.

[11] Barents Observer (2013). "Three oil spills in one year. Another spill is polluting the tundra near the Kharyaga oil field". http://barentsobserver.com/en/nature/2013/10/three-oil-spills-one-year-1410 Accessed on $30^{\text {th }}$ November 2013.

[12] http://www.cbc.ca/news/world/russia-world-s-worst-oil-polluter-nowdrilling-in-arctic-1.1281291 Accessed 30 ${ }^{\text {th }}$ November 2013.

[13] Chamanski, A. (2006). "Statoil experience with UGS", The International Conference "Underground Gas Storage: Sustainability and Efficiency" ("UGS-2006"), 11-13 October 2006, Moscow, Russia.

[14] Statoil. "Sleipner Vest". From Statoil's homepage: http://www.statoil.com /en/technologyinnovation/protectingtheenvironment/carboncaptureandstor age/pages/carbondioxideinjectionsleipnervest.aspx Accessed on $30^{\text {th }}$ November 2013.

[15] Farmer, C. L. and Gurpinar, O. (2003). "Evaluation of Field Management Systems" IPAM, University of California, L. A. Schlumberger presentation top Industrial Problems Study Group, September, 2003, http://www.ipam.ucla.edu/programs/invip/.

[16] OGP (latest version) International oil and gas producers. "OGP Publications". http://publications.ogp.org.uk/?committeeid=22.

[17] OGP (2013). "Environmental performance indicators - 2012 data". OGP, London, Report No 2012e, November 2013. http://www.ogp.org.uk /pubs/2012e.pdf. 